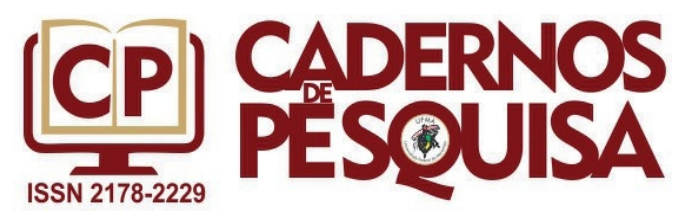

\title{
A FORMAÇÃO DOCENTE EM SERVIÇO NO CONTEXTO DAS REFORMAS EDUCACIONAIS NA AMÉRICA LATINA: um estudo de caso no Brasil
}

\author{
TEACHERS' IN-SERVICE TRAINING IN THE CONTEXT OF EDUCATIONAL \\ REFORMS IN LATIN AMERICA: a case study in Brazil
}

\section{LA FORMACIÓN DOCENTE EN SERVICIO EN EL CONTEXTO DE LAS REFORMAS EDUCACIONALES EN LATINOAMÉRICA: un estudio de caso en Brasil}

Luiz Carlos Novaes

(1) 0000-0002-7320-4595

\begin{abstract}
Resumo
Este artigo analisa a formação em serviço de professores no Estado de Minas Gerais, no âmbito do Projeto Veredas, realizado entre 2002 e 2005 ( $1^{\text {a }}$ fase $)$, tomando como referência o contexto das reformas educacionais que ocorreram na América Latina nesse período e a emergência de novos modelos de formação em serviço voltados à certificação de nível superior. Interessou-nos examinar o modelo pedagógico que se configurou nesse programa, compreendendo que a ideia de modelo de formação docente comporta duas dimensões distintas - os modos de pensar e os modos de operar - que dizem respeito, respectivamente, às crenças, concepções e generalizações, e às maneiras de organizar, aos métodos e procedimentos adotados, materiais utilizados, práticas, de cuja análise depende a identificação da lógica da ação voltada à formação de professores. Para a realização desta investigação foram analisados documentos técnicos e instrucionais relacionados ao Projeto Veredas, com o intuito de conhecer sua arquitetura e seu modus operandi, bem como entrevistas com egressos, com vistas à identificação das implicações de tal projeto na prática pedagógica dos professores. Para tanto, utilizando referenciais das Ciências Sociais, com destaque para as contribuições de Boutinet e Certeau, concluímos que o modelo pedagógico adotado pelo Projeto Veredas, considerando que os modos de pensar e fazer inerentes a tal modelo estão relacionados às premissas teóricas que orientam a organização do currículo e do conhecimento, está alinhado às orientações de organismos internacionais para a formação docente e profundamente marcado por uma hipertrofia da dimensão da prática.
\end{abstract}

Palavras-chave: Projeto Veredas. Modelos de formação docente. Formação em serviço. Reformas educacionais. Minas Gerais. Política Educacional.

\begin{abstract}
This paper analyzes teachers' in-service training in the State of Minas Gerais under the Veredas Project carried out between 2002 and 2005 ( $1^{\text {st }}$ phase $)$, referencing the context of educational reforms ongoing in Latin America during the same period as well as the emergence of new teaching models focused on post-secondary education levels. This paper focuses on examining the pedagogic model set by this program, understanding that the idea of a teaching training model entails two distinct dimensions - thought modes and operation modes - that are respectively about the beliefs, concepts and generalizations and the ways of organizing, the methods and procedures adopted, materials used and the practices that, in order to be analyzed, depend on the identification of the action's logic
\end{abstract}


concerning teachers' training. For this investigation, technical and instructional documents related to Veredas Project were analyzed with the aim of knowing its architecture and its modus operandi, as well as interviews with graduates, in order to identify the implications of such a project in the pedagogical practice of teachers. In order to do so, using Social Sciences references, with emphasis on Boutinet's and Certeau's contributions, we conclude that the pedagogical model adopted by the Veredas Project is aligned with the guidelines of international organizations for teacher education and deeply marked by a hypertrophy of the dimension of practice - considering that the thought modes and operation modes inherent in such a model are related to the theoretical premises that guide the organization of the curriculum and the relationship with knowledge.

Keywords: Veredas Project. Teacher training models. In-service Training. Educational reforms. Minas Gerais. Educational Policy.

\section{Resumen}

Este artículo analiza la formación en servicio de profesores en el Estado de Minas Gerais, en el ámbito del Projeto Veredas, realizado entre 2002 y 2005 ( $1^{\text {a }}$ etapa), teniendo como referencia el contexto de las reformas educacionales que ocurrieron en Latinoamérica en ese período y la emergencia de nuevos modelos de formación en servicio direccionados a la certificación de nivel superior. Nos ha interesado examinar el modelo pedagógico que se configuró en ese programa, comprendiendo que la ideia de modelo de formación docente implica dos dimensiones distintas - los modos de pensar y los modos de operar - que se refieren, respectivamente, a las creencias, concepciones y generalizaciones, y a las maneras de organizar, a los métodos y procedimientos adoptados, materiales utilizados, prácticas, de cuya análisis depende la identificación de la lógica de la acción dirigidas a la formación de profesores. Para la realización de esta investigación fueron analizados documentos técnicos e instrucionales relacionados al Projeto Veredas, con la intención de conocer su arquitectura y su modus operandi, así como entrevistas con egresos, con objetivos a identificar las implicaciones de tal proyecto en la práctica pedagógica de los profesores. Para tanto, utilizando referenciales de las Ciencias Sociales, con énfasis a las contribuiciones de Boutinet y Certeau, concluímos que el modelo pedagógico adoptado por el Projeto Veredas, considerando que los modos de pensar y hacer inherentes a tal modelo están relacionados a las premisas teóricas que orientan la organización de currículum y la relación con el conocimiento, está alineado a las orientaciones de organismos internacionales para la formación docente y profundamente marcado por una hipertrofia de la dimensión práctica.

Palabras-clave: Projeto Veredas. Modelos de formación docente. Formación en servicio. Reformas educacionales. Minas Gerais. Política Educacional.

\section{INTRODUÇÃO}

A discussão acerca da formação de professores na América Latina começou a ganhar visibilidade no final dos anos 1980, fortalecida nos anos 1990 no seio das reformas educativas em curso na maioria dos países da região. Não podemos ignorar, obviamente, a existência de várias recomendações para o campo educacional dirigidas à formação docente, como, por exemplo, a discussão acerca dos "suportes humanos da educação" (ECHEVARRÍA, 1962), que apontava a "má qualidade do corpo docente" como um dos principais problemas da educação latino-americana. Se foi decisiva a influência da Comissão Econômica para América Latina e Caribe (CEPAL) sobre as discussões na América Latina acerca da 
profissionalização e protagonismo docente ao publicar o documento Educación y conocimiento: ejes de la transformación productiva com equidad (1992), não devemos ignorar que essa agência já apontava a necessidade, em 1962, de "preparar, mediante programas emergenciais, o pessoal necessário para satisfazer as necessidades das atividades econômicas e sociais que enfrentarão os países no processo de sua transformação econômica e social” (CEPAL, 1962 apud PEREIRA, 1967, p. 243). Pelos limites deste artigo, não é possível discutir as ações de diferentes organismos internacionais no que tange às recomendações para o campo educacional, especificamente para a formação de professores, mas não podemos deixar de assinalar o acúmulo de tal discussão no cenário latino-americano nos últimos 50 anos.

No final da década de 80 já era possível encontrar várias propostas de formação de professores em serviço na América Latina, com vistas à certificação. Ações decorrentes de iniciativas como "Educação para Todos", "Conferência Ibero-Americana de Educação" e "Plano de Ação Hemisférico da Educação" foram desencadeadoras de normatizações e disposições legais nos diferentes países da região com o intuito de corrigir distorções no campo educacional, dentre elas, as relacionadas à formação docente. Essa rede se fortaleceu e, a partir dos anos 90, a formação inicial docente passou a ser a grande preocupação no continente, tendo, como principal ação, o projeto de Formação Inicial dos Docentes da Educação Básica, que contou com o apoio do governo espanhol.

No final da década já tínhamos um acúmulo de orientações e discussões acerca da importância de se investir em formação inicial e continuada, presencial e a distância, em ambiente de serviço ou fora dele, como estratégia para se atingir bons índices na avaliação da educação básica. Era o fortalecimento do discurso da competência (ou da falta dela) atrelado à formação inicial e à discussão acerca da qualidade da educação básica, levando à tríade competência - formação docente - qualidade (do ensino). Não podemos deixar de lembrar que, segundo a CEPAL (1992), a "capacidade profissional dos professores” guarda uma relação direta com a certificação profissional. Como bem apontaram Popkewitz (1997) e Tenti Fanfani (2005), os professores, vistos como parte dos problemas que envolvem a discussão sobre qualidade, ao mesmo tempo em que se apresentam como solução a estes problemas, acabam se convertendo em protagonistas e obstáculos no discurso reformador. No centro das discussões, a eles se dirigem diferentes políticas e propostas de formação inicial e continuada.

É possível encontrar em diferentes recomendações de organismos internacionais, como o Programa de Promoción de la Reforma Educativa en América Latina y el Caribe (PREAl, 1999, 2001), algumas questões que são comuns às várias propostas de formação em 
serviço dos professores na América Latina, entre elas, a necessidade de elevação da base cultural do professor, uma melhor definição acerca dos conhecimentos que o docente deve ter para poder ensinar e uma maior consideração do lugar onde ocorre o ensino, o que estimula e favorece o trabalho cooperativo.

Saravia e Flores (2005), ao estudarem a formação em serviço em 10 países da América Latina, defendem que as diversas iniciativas e ações voltadas à formação em serviço guardam algumas regularidades, como a ênfase na profissionalização docente, a incorporação do ideário das reformas educacionais e a aposta nas políticas de responsabilização como estratégia para a melhoria do desempenho dos docentes; além disso, identificam a intenção de regularizar uma situação inadequada de formação, tendo em vista os marcos legais adotados nestes países; nesse sentido, como bem apontou Popkewitz e Pereyra (1994), a formação e o trabalho docente acabam subordinadas às novas legislações que orientam a formação docente a partir da criação de novas instituições e modelos de certificação para o exercício profissional que, segundo os autores, representam novas formas de regulação e controle no âmbito do ensino.

A formação de professores na América Latina assume contornos diferenciados, de acordo com as realidades nacionais, contudo, uma breve análise dos modelos de formação docente em curso na região nos revela similaridades e regularidades, sugerindo o que Dale (2000) denominou por agenda globalmente estruturada para a educação. Tal "agenda", segundo Dale, circula por meio de organismos regionais e internacionais, de fundações, de consultores e de grupos de trabalho, no entanto, não é assimilada do mesmo modo pelos diferentes países, já que não ocupam o mesmo lugar no âmbito da economia global, mas, certamente, faz com que temas comuns sejam incorporados às suas agendas. No Brasil, tal como vem ocorrendo em diferentes países da América Latina a partir dos anos 1990, sob a rubrica de formação de professores, abre-se um grande leque de iniciativas que abarca desde projetos de extensão, de caráter episódico, até programas mais elaborados de formação em serviço - presenciais, a distância, híbridos (ou semipresenciais) - que buscam, ora a qualificação de docentes em áreas específicas do currículo, ora a formação mínima preceituada na Lei 9394/96, que define as Diretrizes e Bases da Educação Nacional (LDBEN).

No Brasil, a partir da promulgação da LDBEN, e em consonância com os objetivos explicitados por diferentes organismos para a formação de professores, as políticas educacionais voltadas para a formação dos professores da educação básica reiteraram o discurso de melhoria da qualidade da educação básica por meio da profissionalização docente, mediante frequência a cursos universitários, como já apontou Bello (2008) no estudo acerca 
do processo de certificação do magistério no Brasil. A qualidade da educação e a profissionalização docente foram os pilares que sustentaram, no Brasil, o discurso da necessidade de prover formação universitária aos professores em exercício na rede pública, atuando nas séries iniciais do ensino fundamental.

A exemplo do que ocorria em vários países da América Latina, vários programas de formação em massa foram propostos, em diferentes estados da federação, mantendo sempre um mesmo padrão de organização: cursos híbridos com utilização de tecnologias de ensino a distância, material didático padronizado (materiais apostilados), parcerias com instituições de ensino superior públicas e privadas, presença de tutores, avaliações padronizadas a partir de portifólios e memoriais (ou memórias), entre outros. Trata-se, na verdade, de regularidades que configuram um modelo de formação adotado para resolver um problema estrutural, tratado como emergencial, de tal forma que, extinto o programa, permanece o modelo que poderá ser utilizado em outros momentos e situações de formação.

Interessa-nos, neste artigo, apresentar e aprofundar a reflexão acerca de um dos modelos de formação em serviço colocados em prática no Brasil, com vistas a garantir a formação de nível superior aos docentes em exercício nas escolas públicas brasileiras, com destaque para os professores com atuação nos anos iniciais do ensino fundamental ${ }^{1}$. Para tanto, optou-se por tomar como referencial empírico o Projeto Veredas: formação superior de professores, pela importância que ganhou durante o período pós LDBEN. Pela abrangência e pelo alcance de ação, interessa-nos examinar mais detidamente esse projeto desenvolvido no estado de Minas Gerais pelo fato de ter sido responsável pela formação de um elevado contingente de professores em exercício, conferindo-lhes a certificação de nível superior e envolvendo universidades públicas e instituições privadas, em parceria com o governo do estado $^{2}$, além de ter sido apontado pelo Banco Mundial como um exemplo a ser seguido.

Diante disso, discutiremos os sistemas que integram o Projeto Veredas de modo a compreender sua estrutura organizacional e a consolidação de um modelo de formação, examinando as repercussões sobre a prática docente dos professores egressos.

\section{PROCEDIMENTOS METODOLÓGICOS}

Elegemos como procedimentos de coleta de dados a análise documental e a entrevista semiestruturada com professores cursistas que participaram da primeira fase do

\footnotetext{
1 Os dados aqui apresentados são decorrentes da pesquisa de pós-doutoramento realizada pelo autor na Universidade de São Paulo, com apoio da Fundação de Amparo à Pesquisa do Estado de São Paulo (FAPESP).

${ }^{2}$ Os professores em exercício nas redes públicas do Estado de Minas Gerais, participantes do Projeto Veredas, são denominados neste artigo por professores-cursistas.
} 
Projeto Veredas. Outros agentes como tutores e autores de textos constantes nos guias de estudo e coordenadores de diferentes sistemas que compuseram o Projeto Veredas também foram ouvidos.

Na seleção de documentos optamos por textos impressos e de natureza pública, de caráter normativo, produzidos por órgãos de diferentes instâncias do governo do Estado de Minas Gerais, a partir dos anos 1990 (momento em que várias reformas educacionais estão em curso na América Latina), relacionados à política educacional desenvolvida no Estado e, particularmente, à implantação e consolidação do Projeto Veredas. Também selecionamos um conjunto de materiais pedagógicos (impressos e audiovisuais) editados pela SEE/MG para utilização no projeto em questão. O material instrucional impresso destinado aos cursistas, denominado guias de estudo, está dividido em sete módulos e dois guias de atividades culturais. Cada módulo é composto por quatro volumes, exceto o módulo sete que, além dos quatro volumes regulares, também é composto por um volume denominado Projetos de trabalhos interdisciplinares e três volumes destinados às áreas eletivas (Educação Infantil, Educação de Jovens e Adultos e Educação Inclusiva). Além dos guias de estudos e dos quatro volumes especiais que compõem o módulo sete, também integram o material destinado aos professores dois guias de atividades culturais.

Concomitantemente à análise documental foram realizadas entrevistas com professores cursistas e tutores (alguns deles também autores dos textos constantes nos guias de estudo). Não bastava conhecer apenas como o Projeto Veredas foi desenhado, os seus elaborados sistemas de organização ou os argumentos utilizados pela SEE/MG para sua execução, mas, sobretudo, as repercussões do projeto na prática dos professores cursistas. Desse modo, foram realizadas entrevistas semiestruturadas com 28 pessoas envolvidas diretamente na realização do Veredas em duas instituições de ensino superior, pública e privada, doravante denominadas agências de formação (AFOR) ${ }^{3}$. Pelos limites deste texto trataremos, neste momento, apenas, dos documentos analisados e das entrevistas com os professores cursistas.

A AFOR I, uma instituição privada situada ao nordeste do estado de Minas Gerais, na região do Vale do Jequitinhonha, atendeu 618 professores cursistas (366 da rede estadual e

\footnotetext{
${ }^{3}$ A SEE/MG, mediante edital de licitação, selecionou as instituições de ensino que foram responsáveis pela oferta do curso, sendo 18 instituições de ensino superior, das quais seis eram públicas. Tais instituições foram responsáveis pelos 21 polos (que desdobrados em subpolos totalizaram 29), distribuídos por todo o território mineiro, sob a coordenação de diferentes instituições de ensino, abrangendo diversos municípios. No caso do Veredas os polos ficaram, muitas vezes, a quilômetros de distância, possibilitando ao professor cursista frequentá-lo apenas durante a semana presencial, duas vezes ao ano, e nos encontros mensais. Cada polo teve, aproximadamente, 600 professores cursistas matriculados.
} 
252 das redes municipais) residentes em uma região marcada por muitos contrastes em virtude de seus baixos indicadores sociais. A AFOR II, uma instituição pública, atendeu 563 professores cursistas residentes em área urbana, na região metropolitana de Belo Horizonte. $\mathrm{Na}$ AFOR I foram entrevistados sete professores cursistas e, na AFOR II, 10. Os professores cursistas foram designados por PC e identificados numericamente. Assim, os professores cursistas matriculados na AFOR I encontram-se identificados com a numeração de 1 a 7 (PC1 a PC7) e os professores cursistas matriculados na AFOR II com a numeração de 8 a 17 (PC8 a PC17). No quadro abaixo apresentamos uma breve descrição acerca dos professores cursistas: Quadro 1 - Perfil dos professores cursistas entrevistados e matriculados nas AFOR I e II

\begin{tabular}{|c|c|}
\hline \multicolumn{2}{|r|}{ AFOR I } \\
\hline PC1 & $\begin{array}{l}\text { Professora na rede municipal, } 32 \text { anos, solteira, fez o Curso Magistério de nível médio na rede pública. } \\
\text { Ao ingressar no Veredas contava com } 12 \text { anos de experiência docente na educação infantil. }\end{array}$ \\
\hline $\mathrm{PC} 2$ & $\begin{array}{l}38 \text { anos, } 17 \text { anos de magistério, casada, vinculada à rede municipal, atua na educação infantil. Cursou } \\
\text { magistério de nível médio na rede pública. }\end{array}$ \\
\hline $\mathrm{PC} 3$ & $\begin{array}{l}42 \text { anos, } 19 \text { anos de magistério, casada, vinculada à rede estadual, atua nos anos iniciais do ensino } \\
\text { fundamental, trabalha e reside na zona urbana. Cursou magistério de nível médio na rede pública. }\end{array}$ \\
\hline $\mathrm{PC} 4$ & $\begin{array}{l}44 \text { anos, } 21 \text { anos de magistério, casada, atua nos anos iniciais do ensino fundamental. Cursou magistério } \\
\text { de nível médio na rede pública. }\end{array}$ \\
\hline PC5 & $\begin{array}{l}33 \text { anos, } 11 \text { anos de magistério, solteiro, vinculado às redes municipal e estadual, atua na educação } \\
\text { infantil e nos anos iniciais do ensino fundamental. Cursou magistério de nível médio na rede pública. }\end{array}$ \\
\hline PC6 & $\begin{array}{l}51 \text { anos, } 26 \text { anos de magistério, casada, vinculada às redes municipal e estadual, atua na educação } \\
\text { infantil e nos anos iniciais do ensino fundamental. Cursou magistério de nível médio na rede pública. }\end{array}$ \\
\hline PC7 & $\begin{array}{l}37 \text { anos, } 17 \text { anos de magistério, casada, vinculada à rede municipal, atua na educação infantil. Cursou } \\
\text { magistério de nível médio na rede pública. }\end{array}$ \\
\hline \multicolumn{2}{|r|}{ AFOR II } \\
\hline PC8 & $\begin{array}{l}\text { Professora na rede estadual, } 57 \text { anos, viúva, cursou o "Normal Regional" em } 1960 \text { em instituição pública } \\
\text { e iniciou a docência aos quinze anos em turmas multisseriadas na zona rural, contando com } 40 \text { anos de } \\
\text { experiência no magistério ao ingressar no Veredas. }\end{array}$ \\
\hline PC9 & $\begin{array}{l}\text { Professora na rede municipal, } 28 \text { anos, solteira, fez o Curso Normal de nível médio e Biblioteconomia } \\
\text { em instituições públicas. Trabalhou como bibliotecária na iniciativa privada até ingressar como docente } \\
\text { na rede municipal. Ao ingressar no Veredas tinha três anos de experiência na educação infantil (creche). }\end{array}$ \\
\hline PC10 & $\begin{array}{l}\text { Professora na rede estadual, } 39 \text { anos, casada, fez o Curso Magistério em instituição privada e trabalhou } \\
\text { durante sete anos como secretária de escola. Antes de assumir como professora, na mesma unidade } \\
\text { escolar. Ao ingressar no Veredas contava com } 4 \text { anos de experiência docente nos anos iniciais do ensino } \\
\text { fundamental. }\end{array}$ \\
\hline PC11 & $\begin{array}{l}\text { Professora na rede estadual e municipal, } 46 \text { anos, casada, fez o curso técnico em contabilidade e, depois, } \\
\text { o magistério de nível médio. Trabalhou no comércio na área de contabilidade e, depois de casada, passou } \\
\text { a trabalhar como professora na rede estadual. Ao ingressar no Veredas contava com } 14 \text { anos de } \\
\text { experiência no magistério na rede estadual, ingressando, ao mesmo tempo, como docente na rede } \\
\text { municipal. }\end{array}$ \\
\hline PC12 & $\begin{array}{l}\text { Professora na rede estadual, } 41 \text { anos, casada, cursou o magistério de nível médio em instituição pública. } \\
\text { Professora dos anos iniciais do ensino fundamental, já trabalhou como diretora de escola (eleita). Ao } \\
\text { ingressar no Veredas contava com } 22 \text { anos de experiência docente. }\end{array}$ \\
\hline PC13 & $\begin{array}{l}\text { Professora na rede estadual, } 44 \text { anos, casada, cursou o magistério de nível médio em instituição pública e } \\
\text { curso técnico de enfermagem em instituição privada. Trabalha como auxiliar de enfermagem em } \\
\text { empresa privada e como professora na rede estadual com os anos iniciais do ensino fundamental. Ao } \\
\text { ingressar no Veredas tinha } 18 \text { anos de experiência docente. }\end{array}$ \\
\hline PC14 & $\begin{array}{l}\text { Professora na rede estadual, } 40 \text { anos, solteira, cursou magistério de nível médio e curso técnico de } \\
\text { informática na mesma instituição privada. Trabalhou durante } 3 \text { anos, concomitantemente, em uma } \\
\text { empresa privada, na área de informática, e em uma escola particular, com educação infantil. Ao ingressar } \\
\text { no Veredas contava com } 17 \text { anos de experiência no magistério. }\end{array}$ \\
\hline PC15 & $\begin{array}{l}\text { Professora na rede estadual, } 49 \text { anos, casada, cursou o magistério de nível médio em instituição pública. } \\
\text { Professora nos anos iniciais do ensino fundamental, contava com } 18 \text { anos de experiência docente ao } \\
\text { ingressar no Veredas. Trabalhou como comerciante antes de ingressar na rede estadual, em um pequeno } \\
\text { negócio familiar. }\end{array}$ \\
\hline
\end{tabular}




\begin{tabular}{|c|l|}
\hline PC16 & $\begin{array}{l}\text { Professora na rede estadual, } 47 \text { anos, divorciada, cursou magistério de nível médio em instituição pública } \\
\text { ao mesmo tempo em que trabalhava como empregada doméstica. Após concluir o magistério trabalhou } \\
\text { como auxiliar de ensino em uma creche particular por cinco anos, até ser admitida como professora. } \\
\text { Ingressou na rede estadual e acumulou, até o ingresso no Veredas, com o trabalho na escola privada. Ao } \\
\text { ingressar no Veredas contava com } 17 \text { anos de experiência docente. }\end{array}$ \\
\hline PC17 & $\begin{array}{l}\text { Professora na rede estadual, } 38 \text { anos, casada, cursou o magistério de nível médio e o curso técnico em } \\
\text { patologia clínica, ambos na mesma instituição privada, na condição de bolsista, por ser funcionária da } \\
\text { escola. Após ser aprovada em concurso público para a rede estadual de ensino, onde trabalha com os } \\
\text { anos iniciais do ensino fundamental, deixou o emprego na escola privada. Ao ingressar no Veredas } \\
\text { contava com 15 anos de experiência docente. }\end{array}$ \\
\hline
\end{tabular}

Fonte: Elaborado pelo autor. Dados da pesquisa.

Em relação aos professores cursistas entrevistados e matriculados nas AFOR I e II, verificamos que o perfil do grupo corresponde ao perfil dos ingressantes nestes polos: a maioria é do sexo feminino, casada, com mais de 10 anos de magistério e com idade predominante na faixa dos 30 aos 50 anos.

\section{A ARQUITETURA DO PROJETO DE FORMAÇÃO}

Do ponto de vista da estruturação do projeto, o Veredas apresentou uma organização bastante sofisticada e procurou cobrir os eventuais problemas decorrentes das condições de realização de um curso semipresencial, envolvendo o extenso território mineiro. Como bem lembra Boutinet (2002), ao tratar das perspectivas operacionais de um projeto, é possível identificar três grandes práticas, como as arquiteturais e de ordenamento, as pedagógicas e de formação e, por fim, as de gestão organizacional e tecnológica. O modo de organização dos sistemas básicos no Veredas buscou atender às dimensões apontadas por Boutinet (2002), por meio de tarefas bem definidas e articuladas entre si.

O Projeto Veredas foi organizado em torno de cinco sistemas básicos: um sistema instrucional responsável pela operacionalização do currículo por meio de materiais destinados à realização de atividades pedagógicas; um sistema operacional, que cuidou dos aspectos básicos para a realização das atividades, como inscrições, seleção de cursistas, treinamento de tutores, distribuição de materiais e planejamento das atividades acadêmicas presenciais e a distância; um sistema de tutoria, responsável pelo apoio permanente aos cursistas, compreendendo para este fim o planejamento dos esquemas de acompanhamento das atividades e da prática pedagógica orientada, além das atividades de recuperação, bem como a elaboração de material de apoio e treinamento dos tutores; um sistema de monitoramento e avaliação, para lidar com a avaliação do/no curso, por meio de levantamento de indicadores, definição de instrumentos de coleta de informações, desenhos de fluxos de informações entre os processos de avaliação, monitoramento e avaliação do próprio projeto e, por fim, o sistema 
de comunicação e informação, responsável pela viabilização do funcionamento do sistema de tutoria, garantindo os meios para os contatos entre participantes e tornando ágil o fluxo de informações para o trabalho das instituições envolvidas, servindo, para tanto, de uma secretaria local (da AFOR) e da Web, ainda que de maneira precária, para a consolidação da tecnologia de ensino a distância. Dos sistemas citados, o instrucional funcionou apenas na SEE/MG, sob a responsabilidade da coordenação geral e da equipe de consultores.

Dos cinco sistemas apresentados, os que mais chamam a atenção e constituem a "espinha dorsal" do projeto são os sistemas de tutoria e o de monitoramento e avaliação. Os tutores no Veredas, selecionados de diferentes formas (convite, edital, indicação das prefeituras etc.), foram, em sua maioria, docentes ligados às AFOR. A contratação dos tutores obedeceu a alguns critérios: preferencialmente docentes da AFOR, alunos de mestrado e doutorado na AFOR e com experiência na educação básica, professores da rede pública com curso de especialização ou equivalente. Coube aos tutores não só coordenar os encontros presenciais (uma vez no mês e no início de cada módulo, na semana intensiva), mas, também, acompanhar a prática dos professores, no que foi designado pelo Veredas como "prática pedagógica orientada" (PPO), em substituição ao estágio supervisionado, que consistiu no acompanhamento, nas escolas, das atividades dos professores cursistas, além da orientação na elaboração de memoriais e monografia. Todas as atividades realizadas com os professores cursistas foram avaliadas, mediante registro em fichas específicas, que redundava na nota ao final de cada um dos sete módulos.

O sistema de monitoramento e avaliação, além das atribuições já descritas, parece ter tido a função de corrigir aquilo que Boutinet (2002) denomina por "gestão dos desvios" e ao que preferimos chamar de tensão entre instituído e instituinte. Esse sistema, associado ao de tutoria, cuidou para que fossem mantidas as prerrogativas gerais do Veredas, de modo que o planejado fosse efetivamente executado, permitindo desvios toleráveis e que não comprometessem a "arquitetura" do projeto tal qual foi desenhado.

A formação de professores em exercício no âmbito do Projeto Veredas foi organizada - segundo os documentos orientadores do projeto - com vistas a possibilitar ao professor cursista "avançar em conhecimentos, aperfeiçoar habilidades e qualidades e crescer na sua prática em sala de aula" (MINAS GERAIS, 2002a, p. 21-23). Para atingir tais objetivos o projeto apresentou um conjunto de 15 "competências" que orientariam as diretrizes curriculares do curso, necessárias e desejáveis a um "bom professor", alertando os professores cursistas de que eles já dominavam tais competências e, por isso, o curso lhes daria a oportunidade de ampliá-las, levando-os a desenvolvê-las gradualmente ao longo do processo 
de formação. Para que tais competências, orientadoras das diretrizes do curso, pudessem ser de fato alcançadas, o Projeto Veredas apresentou uma proposta curricular organizada em três grandes blocos: núcleo de conteúdos do ensino fundamental, núcleo de conhecimentos pedagógicos e núcleo de integração.

De acordo com a proposta do curso (MINAS GERAIS, 2002b), o "Núcleo de conteúdos do ensino fundamental", que abrange as áreas "linguagens e códigos", "identidade cultural e sociedade" e "matemática e ciências da natureza", valoriza as experiências culturais dos alunos, os vínculos da educação com o cotidiano e a contextualização dos conteúdos. O "Núcleo de conhecimentos pedagógicos", que se desdobra em "fundamentos da educação" e “organização do trabalho pedagógico", enfatiza a compreensão das dimensões do processo educativo e a reflexão sobre a prática pedagógica e, segundo o documento, “[...] o objeto central desse núcleo é a compreensão das funções sociais da educação fundamental e o compromisso do professor com a construção do sucesso escolar e com a educação de qualidade" (MINAS GERAIS, 2002b, p. 12). Por fim, o "Núcleo de Integração", que compreende o "Eixo Integrador" (identidade do profissional da educação), "Seminários de Ensino e Pesquisa" e os “Tópicos de Cultura Contemporânea", dá prioridade para a discussão acerca dos espaços e tempos voltados para o trabalho interdisciplinar e para a relação teoria e prática centrada na escola em que atua o professor. Nesse núcleo, fica evidente a preparação do professor cursista para a elaboração da monografia e do memorial, por meio dos seminários de ensino e pesquisa, bem como a pretensão de ampliar os horizontes dos professores, seu "universo cultural", levando-os a participar de eventos artísticos e culturais organizados pela agência formadora, por meio dos "tópicos de cultura contemporânea".

As temáticas desenvolvidas pelas áreas "eixo integrador", "seminários de ensino e pesquisa" e "tópicos de cultura contemporânea", diferentes a cada módulo, foram organizadas de modo a colocar em evidência, durante todo o curso, a discussão acerca da elaboração do memorial, da monografia e, principalmente, das práticas pedagógicas orientadas, da qual trataremos mais adiante. Segundo os documentos orientadores do Veredas, tal núcleo assumiu grande importância para o desenvolvimento e ampliação das competências docentes, além de favorecer uma maior articulação entre teoria e prática (MINAS GERAIS, 2002b, p. 11). Para a consolidação deste desenho curricular o curso de formação de professores no Projeto Veredas foi organizado em 3.200 horas, assim distribuídas:

Quadro 2 - Organização das Atividades do Curso de Formação Superior no Projeto Veredas. 


\begin{tabular}{|c|c|c|c|}
\hline \multirow[b]{2}{*}{ Atividades } & \multicolumn{2}{|c|}{ Horas por módulo } & \multirow{2}{*}{$\begin{array}{c}\text { Horas totais } \\
\text { no curso }\end{array}$} \\
\hline & $\begin{array}{c}\text { Horas } \\
\text { semanais }\end{array}$ & $\begin{array}{l}\text { Total por } \\
\text { módulo }\end{array}$ & \\
\hline Atividades da Fase Presencial Intensiva - Semana Presencial & - & 40 & 280 \\
\hline Atividades Individuais a Distância & 10 & 160 & 1.120 \\
\hline Prática Pedagógica Orientada & 10 & 150 & 1.050 \\
\hline Atividades Coletivas Mensais & - & 24 & 168 \\
\hline Atividades de Avaliação & - & 8 & 56 \\
\hline Memorial & $2: 30$ & 40 & 280 \\
\hline Monografia & 2 & 32 & 246 \\
\hline Total & $24: 30$ & 454 & 3.200 \\
\hline
\end{tabular}

Fonte: MINAS GERAIS, 2002b, p.10.

De acordo com o projeto pedagógico do Veredas, as atividades individuais a distância eram destinadas ao estudo sistemático dos conteúdos, além da necessária preparação para os trabalhos interdisciplinares e de integração que seriam desenvolvidos no momento das atividades coletivas. Essas atividades individuais estão explicitadas nos guias de estudo, que contêm, essencialmente, textos básicos para leitura, roteiros para estudo de textos, discussões de vídeos e participação em teleconferências, bem como atividades relativas aos textos básicos e orientações para trabalhos na internet.

Além das atividades da fase presencial e a distância, o Projeto Veredas adotou como alternativa ao estágio curricular supervisionado as chamadas práticas pedagógicas orientadas (PPO). De acordo com o projeto pedagógico do Veredas, as PPO seriam desenvolvidas pelos professores cursistas, com seus alunos, incorporando os conteúdos e atividades realizadas nos estudos individuais e coletivos, o que valorizava a atuação do cursista como professor e promovia seu aperfeiçoamento por meio da aquisição de novos conhecimentos e novas formas de trabalhar. As PPO foram orientadas pelo tutor e planejadas e avaliadas juntamente com o grupo de professores cursistas, quando da realização das atividades coletivas. O planejamento das PPO, orientado pelo tutor, deveria contemplar os planos de aulas que cada professor cursista elaborava para o seu trabalho em cada mês, nas escolas em que trabalhavam, contendo, conforme orientações do Veredas, os seguintes itens: objetivos, conteúdos, atividades a serem desenvolvidas, materiais didáticos e avaliação. Coube ao tutor auxiliar os professores cursistas na elaboração deste planejamento, estimulando-os a incorporar conteúdos e atividades realizadas no curso.

Outras duas atividades completavam a carga horária do curso promovido no âmbito do Projeto Veredas: o memorial e a monografia. O memorial foi definido pelo projeto pedagógico como um "depoimento escrito sobre os processos vivenciados, focalizando, principalmente, a ressignificação de sua identidade profissional e incorporando as reflexões 
sobre a prática pedagógica em uma perspectiva interdisciplinar" (MINAS GERAIS, 2002a, p. 34); assim, segundo as orientações do Veredas:

\begin{abstract}
Analisar a prática pedagógica, em uma perspectiva interdisciplinar, permite que o cursista utilize conceitos, ideias, informações, referências teóricas dos diversos componentes curriculares do curso, articulando-os para analisar, interpretar e compreender a sua experiência pedagógica. [...] Por exemplo, utilizando, logo de início, a concepção de cultura apreendida da Antropologia, situando o mundo cultural em que nasceu - o sistema de significados e de costumes predominantes em sua família e em sua comunidade, os valores, a língua, os hábitos, as relações familiares, o jeito de viver e se expressar. A análise vai crescendo em profundidade à medida que o cursista amplia sua reflexão incorporando a contribuição da Sociologia, discutindo a forma como os saberes e as práticas predominantes em seu grupo familiar se inserem na esfera das relações entre educação, cultura e sociedade. Como esses, todos os demais componentes curriculares têm contribuições importantes a serem captadas. (MINAS GERAIS, 2002c, p. 22-23)
\end{abstract}

Ao longo dos guias de estudo foram apresentadas questões aos professores cursistas com intuito de subsidiar a elaboração do memorial, privilegiando a experiência pedagógica. A discussão acerca da elaboração do memorial era realizada nos encontros mensais, coletivamente, e sob a coordenação do tutor.

Em relação à monografia, o projeto pedagógico determinou que era responsabilidade do professor cursista escolher um tema educacional da atualidade, elaborando a monografia ao longo do curso, com base em estudos interdisciplinares e experiências de integração do ensino e da pesquisa pedagógica (MINAS GERAIS, 2002a, p. 35). Da mesma forma que no memorial, as orientações do Veredas para a monografia destacaram a importância de que essa atividade fosse realizada tendo como horizonte a análise, com rigor, dos "problemas e dificuldades do cotidiano de trabalho da escola ou da sua prática pedagógica, buscando forma de solucioná-los” (MINAS GERAIS, 2002c, p. 29). Ao enfatizar a importância de fazer da experiência ou da prática pedagógica o objeto de investigação na monografia, o Veredas destacava:

Essa modalidade não pode ser confundir com o mero relato do modo como uma experiência foi realizada. Para que possa ser considerada uma monografia o relatório de uma experiência deve problematizar a ação realizada, levantando questões analíticas, e não apenas descrever o que foi feito. É necessário que a monografia seja uma pesquisa, tenha a natureza, os atributos e a qualidade exigida de uma investigação (MINAS GERAIS, 2002c, p. 29).

A avaliação da aprendizagem dos professores cursistas foi desenvolvida ao longo do projeto, sendo realizada, em cada módulo, por meios dos seguintes instrumentos: 
desempenho nos componentes curriculares, observado nas atividades de verificação programada em cada unidade, por meio do Caderno de Avaliação da Unidade (CAU) e nas provas semestrais realizadas ao final de cada módulo; observações do tutor referentes às atividades desenvolvidas, como a PPO e as atividades coletivas, além da análise do processo de elaboração do memorial e da monografia. Tratava-se, portanto, de quatro notas que variavam na escala de zero a cem pontos. Para ser aprovado no módulo o cursista deveria obter, no mínimo, um rendimento de $50 \%$ nas provas de cada componente curricular e $60 \%$ nas categorias memorial, monografia e prática pedagógica orientada.

A avaliação do memorial e da monografia foi realizada em cada módulo e ao final do curso; para tanto, foram sugeridos ao tutor alguns aspectos que deveriam ser observados mensalmente e registrados em fichas específicas. Caso o cursista não obtivesse um rendimento igual ou superior a $60 \%$ na preparação do memorial e da monografia, seria orientado pelo tutor sobre como melhorar e compensar tal desempenho nos módulos seguintes. A avaliação das PPO obedeceu a um minucioso roteiro de observação do espaço físico da escola e da sala de aula, do material didático utilizado, do processo de ensino e aprendizagem (nesse caso, eram verificadas a adequação/inadequação do conteúdo, a forma de incentivo aos alunos, a proposição de trabalhos coletivos, o preparo e correção de atividades, a organização do tempo, a avaliação, entre outros), da dinâmica da sala de aula etc. De acordo com as diretrizes de avaliação do cursista expressas no Projeto Veredas, após a visita à escola cabia ao tutor conversar com o cursista, devendo essa conversa ser direcionada, quando se tratasse de comportamentos e objetivos passíveis de mudanças; oportuna, que deveria ser o mais próximo possível em que a ação ocorreu e; esclarecedora, direta e precisa, para não dar margens a outras interpretações (MINAS GERAIS, 2002c, p. 40). O registro da PPO foi realizado em ficha específica, detalhada em tópicos e subtópicos a serem observados.

Mesmo sendo caracterizado pela SEE/MG como um curso a distância, de caráter semipresencial, o Veredas não fez uso da internet como uma tecnologia de ensino. Embora desejável, como expresso nos guias orientadores do projeto, o uso da internet não foi uma condição para a realização do curso, já que a maioria dos professores cursistas, naquele momento, não tinha condições para tal. Dada a dificuldade na utilização de recursos tecnológicos, o curso foi organizado, fundamentalmente, com materiais instrucionais impressos: guias de estudos e cadernos de avaliação unificados (CAU) que os cursistas preenchiam e enviavam ao tutor pelo correio ou entregavam diretamente na sede da AFOR, antes dos encontros presenciais, além dos vídeos utilizados ao longo do desenvolvimento dos módulos. 
Durante as entrevistas procuramos saber o que os professores cursistas tinham a dizer acerca das atividades desenvolvidas ao longo do Veredas, a repercussão sobre a prática pedagógica, como as avaliavam em relação à organização e realização, bem como a sua importância para o processo de formação. É disso que trataremos a seguir.

\section{E O QUE DIZEM OS PROFESSORES CURSISTAS? AS REPERCUSSÕES SOBRE A PRÁTICA PEDAGÓGICA}

Nas entrevistas com os professores cursistas ficou evidente como a valorização da dimensão da prática parece ter constituído o núcleo da organização do Projeto Veredas. Avaliada de maneira altamente positiva pelos professores cursistas e tutores, a centralidade da prática ao longo do curso surge nos diferentes discursos como uma inovação, um diferencial em relação aos cursos presenciais. Para uma professora cursista a valorização da prática dos professores foi a maior preocupação do Veredas:

Eu gostei de ter feito o Veredas. Significou muito para mim, transformou o meu jeito de dar aulas, de ensinar. Quando comecei a dar aulas, há mais de 15 anos, achava que sabia tudo - como preparar uma aula, dar e corrigir exercícios, preparar prova, avaliar. Enquanto eu fazia o Veredas já procurava ir aplicando aquilo que ia aprendendo, um novo jeito de dar aula de Artes, de ensinar História ou utilizar materiais diferentes para ensinar Matemática. Hoje vi que não sabia nada, não sabia, por exemplo, a explorar a leitura de um texto, de fazer os alunos interpretarem, de escreverem. Isso aprendi no Veredas. No Veredas a gente estava, a todo momento, falando sobre o que fazíamos, sobre nossos alunos, nossas escolas. A gente preparava plano de aula durante o curso, discutíamos com os tutores e com nossos colegas, às vezes até de nossas escolas. Tinha também os cadernos com os textos, que também eram importantes, nos apresentava uma porção de coisa nova e, afinal, também caia na prova do módulo e tínhamos que usar na monografia [risos], mas na hora de falar sobre como ensinar alguma coisa, uma técnica nova, um jeito diferente, bom, aí era diferente, era mais animado. Procurávamos fazer bem os planos de aula para quando o tutor fosse a escola acompanhar a prática pedagógica. Hoje eu sou uma professora melhor. (PC15)

Para a PC15 a valorização da dimensão da prática ao longo do curso a ajudou modificar sua forma de trabalhar, no entanto, não atribui às discussões dos textos a mesma importância, relegando-os à necessária utilização na elaboração da monografia ou, ainda, para as provas finais de cada módulo. Ao se referir ao plano de aula, elaborado coletivamente durante os encontros presenciais, a professora cursista chama a atenção para o acompanhamento da prática pedagógica por parte do tutor, em visita às escolas. 
As PPO tinham uma dupla finalidade: era a aplicação direta que as professoras cursistas faziam daquilo que haviam discutido na semana presencial ao preparar seus planos de trabalho, juntamente com as demais cursistas e tutores, mas, também, na organização do Veredas constituía a carga horária destinada ao estágio supervisionado. As PPO eram avaliadas pelo tutor, juntamente com as provas semestrais, monografia e memorial, e compunham a nota final de cada etapa. Perguntado a todos os professores cursistas acerca da principal inovação do Veredas, a PPO aparece com unanimidade.

Duas questões chamam atenção em relação às PPO. A primeira, a assunção pela maioria dos entrevistados acerca do aspecto inovador da ação. Não podemos deixar de lembrar que o acompanhamento in loco da atuação de futuros professores, durante o estágio supervisionado, já foi uma prática corriqueira desde os primeiros cursos de formação de professores em nível médio no Brasil, quando o professor orientador de estágio se deslocava até as escolas para "fiscalizar" o cumprimento do estágio por parte do futuro professor. A "docência supervisionada", através da qual futuros professores exercitavam a prática profissional, em situações muitas vezes fictícias e irreais, assumiu contornos variados ao longo da história da educação brasileira, não sendo, por si, uma novidade; nesse sentido, no caso das PPO desenvolvidas no âmbito do Veredas, a novidade parece residir no fato de que as situações vividas pelas professores cursistas são reais, em situações reais e no próprio ambiente de trabalho.

A segunda observação acerca das PPO diz respeito à polarização "prática antiga", antes do ingresso no Veredas, e "prática nova", depois do Veredas, presente nos depoimentos de muitas professores cursistas. A esse respeito, e lembrando do alerta de Bourdieu (2009) de que muitas vezes a melhor forma de falar da prática é a de maneira negativa, uma das formas encontradas de valorizar o próprio processo de formação, diferenciando-o dos demais (nesse caso, os cursos presenciais), é apresentar o curso, e de maneira particular as PPO, como um sinal distintivo de qualidade, mostrando como o "tradicional" agora é "inovador", o que pode desconsiderar, como bem adverte Chartier (2000), "a existência de toda uma série de ações profissionais ordinárias que constituem o tronco sobre o qual vêm se enxertar os estilos pedagógicos ou didáticos específicos, tradicionais ou renovados" (CHARTIER, 2000, p. 164).

Não se trata de recuperar, nessa breve reflexão, a discussão acerca da costumeira polarização teoria-prática ou, ainda, entrar na não menos problemática seara tradicionalinovador. Trata-se, apenas, de evidenciar a percepção de tutores e cursistas acerca daquilo que julgam inovador, o grande diferencial deste projeto de formação, que é a epistemologia da prática e a valorização de um discurso acerca do desenvolvimento das competências e 
habilidades profissionais, materializado, ao longo do curso, no fortalecimento dos modos de fazer.

O ingresso no Projeto Veredas foi, logo no início, para um grupo de professoras, encarado como uma obrigação; na fala de uma cursista, um "mal necessário" (PC6). Depois, com o tempo, muitas afirmaram que passaram a gostar do curso e a se interessar pelas atividades que eram realizadas.

Já estou no magistério há 18 anos e, vou dizer a verdade, eu não achava que o curso ia me acrescentar muita coisa. Não estou dizendo que sei tudo ou que não preciso aprender mais nada, não é isso, mas a gente já não aguenta mais tanta propaganda, tanto cursinho disso, tanto cursinho daquilo. Foi com esse espírito que fui fazer o Veredas, meio que por obrigação, por causa do nível superior. Depois, a partir do segundo encontro, fui me interessando, fui percebendo que o curso valorizava tudo aquilo que a gente fazia, ensina, dava dicas, estimulava a gente a aprender, sem contar a qualidade dos professores e tudo o que a universidade propiciava. (PC13)

Eu gostei de fazer o Veredas, mas não senti grandes diferenças do magistério que eu fiz. É claro que o tempo passou e muita coisa surgiu, como em qualquer setor da vida. A vantagem do Veredas foi o diploma mesmo, porque com isso eu melhorei o meu salário e, além do mais, eu jamais teria condições de pagar uma faculdade. Não estou dizendo que o curso foi ruim, pelo contrário, aprendi bastante coisa nova, mas acho meio injusto muitas colegas dizerem que aprenderam tudo no Veredas. E o que você estudou antes? E os cursos de capacitação do Estado? E a sua experiência? Nada isso conta? (PC6)

Para outras cursistas era um "sonho" a possibilidade de terem em mãos um

diploma de curso superior, de serem respeitadas por isso e de poderem falar "de igual para igual":

Eu me julgava uma boa professora, as pessoas diziam que eu era uma boa professora, mas, mesmo assim, eu queria esse papel, esse certificado que a universidade iria me dar, pra poder discutir de igual para igual, para ser mais respeitada. Eu sou competente, sei que sou, mas estava frustrada. (PC12)

Quando soube do Veredas eu fiquei entusiasmada. Era minha chance de fazer faculdade, sabe, de ter um diploma. Na minha família ninguém tinha conseguido chegar ao ensino superior. Com muito sacrifício pude ainda fazer o magistério e me formar professora. Isso era muito importante, não por causa do aumento de salário, mas pelo orgulho, por não me sentir menor do que as outras pessoas. (PC3)

Outro relato que chamou a atenção foi do PC5, o único professor do grupo e, segundo ele, também no polo em que estudou.

[...] Faltava uma coisa na minha vida: ter um curso superior. Eu sempre desejei fazer um curso de Letras, trabalhar com literatura, com a escrita 
mesmo. Quando apareceu o Veredas vi que aquilo seria muito bom para mim. Até que enfim eu poderia ter uma formação superior e só dependeria do meu esforço, da minha dedicação. Comecei o curso assim, cheio de expectativas [...] Mas eu tinha aquele desejo de fazer o curso, ainda mais para mim, que as coisas nunca foram fáceis. É difícil você ver um professor de educação infantil, geralmente são professoras, não é? Então, eu tinha que provar que um homem podia ser um bom professor de educação infantil e de primeira à quarta séries. No ensino fundamental as pessoas já estavam até acostumadas, mas na educação infantil não. $O$ Veredas me ajudou a ser este professor melhor e a mostrar para as pessoas como eu sabia o que estava fazendo. Minhas aulas melhoraram, passei a usar coisas novas que aprendia no curso, com o relato de outras professoras, com as sugestões dos tutores. Minha prática é outra, mas sinto que preciso continuar aprendendo, a buscar as coisas, porque o conhecimento é assim, não acaba. Se tivesse um Veredas pós-graduação eu faria [risos]. Depois do curso fiquei mais seguro e, agora, diplomado. (PC5)

Foram entrevistadas 17 (dezessete) cursistas e todos relataram sua trajetória profissional até ingressarem no Veredas, marcadas, na maioria das vezes, por muitas dificuldades.

Toda vida tive vontade de estudar, mas como a gente vinha assim numa vida apertadinha, na minha casa eram 11 irmãos e eu a mais velha, então eu fiz um curso chamado Curso Normal Regional, que com quatro anos você já podia ser professor. Então eu fiz esse curso e com quinze anos eu estava com o diploma na mão e então eu fui trabalhar. Isso era 1960. Eu fui trabalhar na roça com crianças de $1^{\mathrm{a}}, 2^{\mathrm{a}}$ e $3^{\mathrm{a}}$ séries, todas juntas na mesma sala, no interior de Minas. Quando foi em 1963 mudei de cidade e trabalhava na Belgo Mineira e em escola do Estado. Foi aí que comecei o segundo grau, mas parei no segundo ano, porque eu casei e o meu esposo achou que eu não devia continuar estudando. Depois mudei para Belo Horizonte e fiz o supletivo segundo grau. Queria continuar estudando, mas eu já tinha seis filhos, assim de dois em dois anos, então não dava pra voltar estudar. Quando veio o Veredas eu estava dando aula na prefeitura e já era aposentada em um cargo no Estado, com aquele curso que fiz em 1960. (PC8)

Já aposentada na rede estadual e com outro cargo efetivo na rede municipal, essa cursista expressa o desejo de fazer um curso superior como "um sonho". Mesmo assim, a professora não deixa de reconhecer as dificuldades que enfrentou para organizar sua vida e fazer o curso:

Minha maior dificuldade pra fazer o Veredas foi a questão do tempo. Eu não deixei de ser professora, mãe e dona de casa e tinha, ainda, que passar a ser cursista. A gente fica o dia inteiro, aos sábados e, depois, tinha muita coisa pra fazer em casa. $\mathrm{O}$ transporte também não foi fácil, pois minha casa fica a quase duas horas da universidade. Pra estudar eu fazia assim: fazia todo o serviço da casa primeiro, enquanto estava todo mundo acordado, depois eu dormia umas três ou quatro horas e levantava de madrugada para estudar e fazer as atividades. Era o melhor horário para mim. (PC8) 
O relato da PC8 acerca das dificuldades enfrentadas foi reiterado por outras cursistas e com certa regularidade: origem humilde, dificuldades econômicas, necessidade de ajudar em casa economicamente e nas tarefas rotineiras etc. Para uma das entrevistadas, "a maior dificuldade foi a falta de um horário para estudar, pois, com casa, filhos, marido e escola, não sobrava muito tempo"; então, prosseguia, "eu acordava às quatro horas da manhã e estudava até as seis, todo dia; depois era começar a rotina do dia, que ia até a noite" (PC11). Apesar destas e de outras dificuldades enfrentadas, todas as entrevistadas afirmaram ter gostado do curso e da maneira como foi organizado, não existindo diferenças significativas em relação à avaliação do curso pelas professoras cursistas das duas AFOR.

Em relação às atividades a distância que envolviam a leitura do material instrucional e os preenchimentos dos $\mathrm{CAU}$, as professoras cursistas foram unânimes, não havendo diferenças entre os dois grupos. Para elas, o material instrucional adotado no Veredas foi de boa qualidade; no entanto, tinham maior dificuldade em compreender os textos de alguns componentes com os quais não estavam familiarizadas, com destaque para Filosofia, Sociologia e Antropologia. As professoras cursistas consideraram esses conteúdos "mais difíceis", justificando que encontraram maior facilidade com os demais conteúdos dada a proximidade com o que já trabalhavam na escola.

Não tenho o que reclamar dos guias. Eram ótimos! Eu tinha um pouco de dificuldade em algumas matérias, mas não era culpa do material. Muito tempo sem estudar e sem professor por perto, já viu. [...] Eu peguei recuperação em Artes, Antropologia e Filosofia. É muito difícil trabalhar com a Arte, eu não imaginava que fosse assim. Filosofia também eu achei difícil, muitas leituras complexas. Português, matemática, Ciência...aquilo que a gente já trabalha, isso não teve dificuldade. Mas como trazer Filosofia e Antropologia para a prática? Complicado, né? O problema mesmo é quando a gente tinha que fazer os CAU. A gente se reunia e tentava fazer juntas, mas nem sempre conseguíamos. (PC10)

Como os CAU eram preenchidos e entregues antes dos encontros presenciais, como determinava o Veredas, muitas professoras cursistas disseram que não se saiam bem em algumas matérias em virtude desta falta de familiaridade com alguns conteúdos. De maneira geral, as atividades individuais a distância tinham para os entrevistados uma dificuldade de nível médio, muito mais pela falta de tempo do que, necessariamente, pelas dificuldades com o material instrucional.

$\mathrm{Na}$ avaliação das professoras cursistas os encontros coletivos mensais e as semanas presenciais foram muito importantes e as ajudavam muito na realização do curso. Perguntadas quais atividades do Veredas mais contribuíam para a prática pedagógica, as cursistas foram unânimes em afirmar que, em primeiro lugar, estava a PPO, em segundo, as 
atividades coletivas mensais e, em terceiro, as atividades presenciais. Na sequência apontaram, por ordem de importância, as atividades individuais a distância, a elaboração do memorial, a elaboração da monografia e, por último, a avaliação (referindo-se aos CAU e à prova final).

As atividades presenciais, tanto as mensais como as semanais intensivas, eram vistas pelas professoras cursistas como momentos não só de tirar dúvidas sobre o preenchimento dos CAU, mas, sobretudo, para conversar com o tutor sobre a PPO e sobre a elaboração do memorial e da monografia. Além disso, nas semanas presenciais eram desenvolvidas as chamadas atividades culturais, muito comentadas pelas cursistas. É preciso lembrar que as atividades das semanas presenciais eram de responsabilidade das AFOR, o que as tornavam diferentes de uma agência para outra, no entanto, em relação ao que disseram as cursistas acerca destes encontros presenciais, não houve diferenças significativas entre os dois grupos, que avaliaram esses encontros de uma maneira bastante positiva. Dois depoimentos ilustram bem a percepção das cursistas, das duas AFOR, acerca das atividades realizadas nas semanas presenciais intensivas:

A semana presencial era muito cansativa por causa da viagem, mas era bacana. Nesse dia a faculdade organizava várias salas com eventos, oficinas, exposições, muitas atividades mesmo. Também eram apresentados os conteúdos que seriam trabalhados naquele semestre, nos encontros mensais. Em relação às oficinas eu me lembro da oficina de matemática em que uma professora da faculdade nos ensinava a trabalhar com jogos matemáticos, de uma de literatura em que uma aluna de um curso presencial da AFOR nos mostrava um jeito de trabalhar com contação de estórias e de uma oficina de Artes onde uma professora cursista mostrava como ela trabalhava com colagem e escrita ao mesmo tempo. Eram sempre oficinas que nos mostravam algo novo, coisas que a gente podia fazer com nossos alunos [,,,] Também tinha os projetos, como o projeto interdisciplinar meio ambiente é vida, onde a gente saia a campo e discutia as várias formas de estudar a ambiente, das relações possíveis, de como trabalhar isso com os alunos. Muita coisa que aprendi nestas oficinas eu passei a fazer com meus alunos. (PC4)

Todos os dias tinha coisas relacionadas com prática. No dia da apresentação dos conteúdos de Artes, por exemplo, acho que foi na quinta semana presencial, não tenho muita certeza, teve uma porção de atividades de arteeducação: lembro que foram umas vinte oficinas e a gente nem sabia direito qual fazer porque algumas aconteciam no mesmo horário. Na época a tutora recomendou que fizéssemos pelo menos uma oficina de cada linguagem, aí eu fiz uma chamada arte mural, que trabalhava com grafite, atividades de musicalização, que era voltada para a percepção sonora e trabalhava com a linguagem musical e uma chamada expressão, ritmo e movimento, que era sobre expressão corporal e jogos teatrais. Nesta semana eu fiz mais oficinas, mas não sei te dizer por nome, mas era tudo na área de Artes. Na área de literatura também teve bastante oficina. Tinha muita coisa acontecendo nas semanas presenciais e a gente não dava conta de participar de tudo, mas as apresentações dos conteúdos dos módulos eram obrigatórias. (PC14) 
Nas semanas presenciais, as AFOR deveriam apresentar os conteúdos que seriam trabalhados ao longo do semestre, nas atividades mensais, bem como intercalar tais apresentações com atividades culturais, mais lúdicas, sem perder o foco das contribuições que tais atividades pudessem dar para a reflexão dos temas que seriam abordados nos volumes daquele módulo para a prática das cursistas. As atividades mais valorizadas pelas cursistas durante a semana presencial eram as oficinas. Embora a programação das duas AFOR apresentasse para estas semanas palestras com temáticas variadas, nenhuma delas chegou a ser mencionada pelas professoras cursistas das duas AFOR.

Para mim os encontros presenciais eram bons. Era o momento de ficar cara a cara com o tutor, de tirar dúvidas, de perguntar as coisas. Isso faz falta, ter uma pessoa para tirar a dúvida assim que ela aparece, se bem que o material não era de dar muita dúvida. Nos nossos encontros mensais a tutora fazia a correção dos CAU, passava o vídeo e nós comentávamos, devolvia os rascunhos do memorial ou da monografia que a gente tinha deixado com ela e de trabalhos corrigidos do encontro anterior. $\mathrm{O}$ dia passava que a gente nem via. (PC17)

Era muito bom o encontro presencial. A gente encontrava colegas de outros municípios, encontrava a tutora, era um dia dedicado só para estudar, longe de casa. Esses encontros eram necessários porque a gente tinha muitas dúvidas, não só com os CAU, mas também com coisas dos textos, com o memorial e com a monografia. Eu lia os guias e ia destacando o que eu não tinha entendido. Com os CAU eu fazia a mesma coisa - copiava as questões que eu tinha tido dúvidas pra responder. Nos encontros eu procurava tirar essas dúvidas, afinal, era pra isso que eu estava ali, não é? (PC5)

Das professoras cursistas que não consideraram o encontro mensal positivo, destacamos o depoimento abaixo:

É claro que precisava ter um encontro presencial, mas de outro jeito. Pra começar, não deveria ser aos sábados, depois de uma semana de trabalho. Custava a secretaria liberar a gente uma vez, só uma vez ao mês para esse dia presencial? Tinha que ser no final de semana? Já não bastavam duas semanas das férias? Veja, isso não tem a nada ver com o curso! No geral, eu achei o Veredas ótimo, estou falando desta organização, só isso. Em relação aos encontros mensais penso que era muita coisa para um dia. Era um volume inteiro para discutir - você sabe, né, cada módulo tinha quatro volumes, então, era um volume por encontro - muita coisa para ler e estudar, orientações de memorial e monografia, correção de CAU. O vídeo a tutora às vezes nem passava e, quando passava não tinha muito tempo para o debate. Não achei que esse jeito de trabalhar da tutora foi positivo para minha prática. Em nenhum momento a gente foi consultada sobre tudo isso. A coisa já estava pronta. Não dizem que não podemos fazer assim na escola? $\mathrm{Na}$ hora que a discussão estava ficando interessante tinha que parar e a sensação que me ficava é que nunca conseguíamos terminar nada. Esses encontros eram muito cansativos por causa de tudo isso (PC6) 
Mesmo quando teciam críticas aos encontros mensais, as cursistas insistiam em separar isso do julgamento que faziam do Curso Veredas. A principal crítica de todas as cursistas aos encontros mensais diz respeito ao excesso de atividades e à organização do tempo; para algumas, esse excesso de tarefas levava a uma descontinuidade dos trabalhos, marcado, por exemplo, pela interrupção de uma discussão por causa de outra atividade ou, ainda, ao tratamento superficial de questões que julgavam importantes e que mereciam maior espaço, o que talvez pudesse ser resolvido, segundo a PC14, se houvesse interação virtual, o que não acontecia no Veredas.

Ficou evidente em todas as entrevistas como a elaboração do memorial e da monografia foi, desde o início, encarada pelas professoras cursistas como tarefas de difícil elaboração; apesar disso, para todas elas foi importante realizá-las.

A minha maior dificuldade com a monografia foi a minha falta de leitura
mesmo. Eu não sabia o que era um texto acadêmico, não sabia que autor usar.
Nunca tinha feito aquilo. A tutora foi ajudando durante o curso, ia lendo e
devolvendo, pedindo pra gente refazer. Mas foi muito difícil. Ainda por cima
eles exigiam que fosse feito tudo no computador e, naquele época, eu não
tinha computador em casa. O memorial também não foi fácil fazer. A tutora
dizia "não é diário", é pra ir falando da sua vida, da sua trajetória. A gente
começa a pensar e parece que não tem nada de importante pra dizer. Foi um
desafio, gostei de fazer, mas foi muito, muito difícil. (PC4)

Não era apenas a avaliação do memorial e da monografia que trazia desconforto às professoras cursistas; existiam, como já apontamos, os CAU e a prova final do módulo. Podemos perceber nos relatos das cursistas como o tratamento dado ao CAU variava muito, dependendo do tutor; mesmo assim, não era uma atividade da qual elas falaram com entusiasmo.

Aqueles CAU era uma tortura. A gente vinha pra casa já com aquela
obrigação na cabeça. O meu tutor queria que a gente enviasse o CAU pelo
menos uma semana antes do próximo encontro, o que nos dava menos de um
mês, às vezes, pra fazer tudo aquilo. Algumas colegas ainda podiam dividir
esse trabalho com uma outra cursista, da mesma escola, mas eu não tinha
ninguém. No nosso grupo, as pessoas eram de cidades diferentes. O tutor
corrigia os CAU e no encontro mensal ia comentando com a gente as
respostas corretas, tirando as dúvidas. Só que aí o estrago já estava feito, né?
Não podia mais alterar as respostas. (PC1).

Se, para uma das cursistas, o preenchimento do CAU não foi um problema, já que em seu grupo várias cursistas eram da mesma escola e, reunidas, realizavam juntas esse trabalho, para outras, que não podiam contar com a mesma oportunidade, essa tarefa era difícil. O procedimento adotado pelo tutor da PC1 era o que indicava o projeto pedagógico do Veredas, no entanto, como afirmou uma professora cursista, muitas vezes os tutores já 
“acertavam” esses CAU na ocasião das visitas às escolas, quando lá havia várias cursistas, ou então, resolviam esses cadernos, coletivamente, no encontros presenciais.

A prova mensal era sempre um momento tenso. Ainda que essa prova reunisse todos os componentes curriculares, a atribuição de pontos se dava separadamente, por componente curricular. Para algumas cursistas era difícil estudar "quatro volumes para uma prova e, por isso, seria melhor se fosse como ocorre escola, por bimestre" (PC2); para outra, a única saída era "decorar o conteúdo e, assim mesmo, não dava pra fugir da dor de barriga e da boca seca" (PC6) e para outras ainda era "muita incoerência isso, pois eles pediam detalhes insignificantes na prova, pegadinha mesmo, que nem tinha sido tão discutidos" (PC13). Para o PC5 o problema das provas estava, muitas vezes, na "chave de correção" à qual, para ele, muitos tutores ficavam apegados demais:

Muitas vezes eu não concordei com as respostas da correção da prova. Por mais que a tutora insistisse, a gente via que aquela resposta não poderia ser a certa. Mas não adiantava: se estava na chave de correção, então não tinha como reclamar. A gente soube que, em outros grupos, até mesmo em outras AFOR, tinha tutor que mudava essa chave, principalmente quando era da área dele. Se ele, que é especialista naquele assunto, tá vendo que a resposta apontada como certa na chave de correção na verdade não é aquela, por que insistir? Mas, na maioria das vezes, o tutor não era daquela área, então ele não considerava outra resposta, só aquela do gabarito mesmo, entendeu? Não sei se estou falando alguma bobagem, mas não combinava o que o Veredas falava de avaliação e o que eles faziam com aqueles CAU e a prova final. (PC5)

O trecho do PC5 traz uma questão bastante presente nos depoimentos dos dois grupos de cursistas: a relação com a tutoria. De maneira geral, a maioria destacou o bom relacionamento entre professores cursistas e tutores, mas não deixaram de apontar o que, para eles, foram entraves em alguns momentos:

Minha tutora era muito bacana, super gentil, mas ela não dava conta de orientar 15 memoriais e 15 monografias. Além disso, ela corrigia também os CAU e tinha lá suas tarefas, como todas nós. Eu achava que era muita coisa para uma pessoa só. Em muitos encontros mensais a gente nem tinha muito tempo de tirar dúvidas, e não é porque ela não queria, é porque não dava mesmo. (PC4)

\section{Para outras cursistas}

Às vezes pensava que minha tutora não sabia bem o que acontecia em uma sala de aula de primeira série. Não é possível. Ela falava umas coisas para a gente, coisas que a gente teria que fazer, que tava na cara que não iria dar certo. Pense em colocar uma tela, tinta e mandar mais de trinta crianças fazerem uma releitura de uma obra de arte! Já imaginou isso? Sem contar que não existe dinheiro nem para a tela, nem para a tinta. E os filmes que ela recomendava? Olha, é muita distância da realidade. A maioria dos tutores não sabiam o que acontecia dentro de uma escola. Alguns até eram 
professores da rede pública, mas trabalhavam com o ensino médio, não com crianças pequenas. (PC3)

Muitas vezes os tutores nem conseguiam resolver exercícios, claro que eles não tinham que saber tudo, afinal, cada um tinha uma formação, mas veja, não era para isso que eles estavam ali? Depois vinha aquele discurso de que a gente precisava aprender a aprender. Pode ser bonito, mas se não tiver quem ensine não tem jeito. Eu não me imagino mandando meu aluno da primeira série aprender a aprender. Mas também não quero ser injusta. Teve coisas boas sim, aprendi coisas novas, algumas técnicas, formas diferentes de fazer aquilo que eu já fazia. (PC6)

As críticas aos tutores, seja pela falta de tempo ou pela inadequação de suas intervenções, foram mais comuns entre as professoras do Vale do Jequitinhonha. Para as professoras cursistas residentes em Belo Horizonte não houve críticas em relação à atuação dos tutores, pelo contrário, todas destacaram o bom relacionamento com o tutor e elogiaram o trabalho por eles realizado:

A tutora teve chance de acompanhar nosso progresso, ajudar em nossas dificuldades - principalmente na monografia e no memorial - e isso não deixava a gente perdida, havia segurança. Isso também criou laços, vínculo afetivo mesmo. Mesmo quando dava vontade de faltar eu lembrava da tutora e pensava - ela merece nossa presença, não vou faltar - era respeito, sabe? Minha tutora foi excelente! Eu percebi que isso aconteceu em todos os grupos, a maioria dos cursistas criou vínculo com a tutoria. (PC9)

Gostei de muitas coisas do Veredas, mas, principalmente, de como os tutores valorizavam a gente e o que a gente fazia na escola. Nunca fiquei sem uma resposta. Quantas vezes a minha tutora não me convidou para vir às aulas da Pedagogia? Nunca deu para vir, mas ela sempre foi muito disponível, até fora do horário ela me atendia (PC15).

A tutora era ótima, levava sugestões, indicava materiais; aos poucos fui aplicando algumas coisas na escola, durante a visita do tutor, e vi que dava certo, que muita coisa funcionava. A gente via que ela sabia do que estava falando, que ela dominava aquele assunto. Sempre senti segurança nas orientações da minha tutora e, além do mais, ela era muito educada, fina mesmo. A grande contribuição do Veredas não foi tanto a teoria, foi isso de melhorar a prática da gente, arejar aquilo que a gente já sabia fazer, mas, agora, de um modo melhor. (PC7)

Entre as professoras cursistas de Belo Horizonte havia um orgulho muito grande em terem feito o curso naquela AFOR e com aqueles tutores, na sua maioria autores do material utilizado. A referência aos tutores e à instituição era sempre elogiosa. Para a PC12, por exemplo, "só a grife da instituição já fazia com que elas fossem mais valorizadas na escola".

Os nossos colegas que não estavam fazendo o Veredas falavam da nossa empolgação. Não era por mal, mas eles não deixavam de dizer que 
estávamos empolgados demais. E não era para estar? Fazer o curso superior e nessa universidade? Não era para qualquer um! [...] Tem um peso muito grande, porque é uma instituição muito boa. Eu me sentia muito importante fazendo o Veredas (PC9)

A escola se mobilizou para dar conta de atender ao Veredas, às cobranças das professoras cursistas, às demandas da universidade, e é claro que isso mexeu com aqueles professores que já eram formados. No início os colegas não acreditavam muito na gente, eles falavam "ah, esse cursinho não vai dar em nada, isso não é curso universitário". Depois eles começaram a ver com outros olhos. Eles viram que nosso curso era bom e que nós estávamos até melhor preparados que muita gente que tinha feito curso presencial em faculdades privadas. Nós estávamos em uma ótima universidade. Nossos tutores eram professores de lá e muitos autores conhecidos, inclusive do material do Veredas. Isso não era pouca coisa. (PC11)

A imagem que as professoras cursistas de Belo Horizonte tinham da AFOR e dos tutores era altamente positiva, o que não foi percebido nas professoras cursistas do Vale do Jequitinhonha. De todo modo, nos dois grupos, não foi relatado nenhum tipo de discriminação por parte dos docentes das escolas em que estas cursistas trabalhavam, pelo contrário, a referência à escola e aos demais colegas foi sempre no sentido de que estes valorizaram o processo de formação e incentivaram as cursistas na realização das atividades obrigatórias, como as PPO, além de colaborarem quando eram solicitados.

Nesta discussão acerca da relação com a tutoria, a PPO esteve presente nos depoimentos de todas as professoras cursistas, atividade em que o tutor ocupava um lugar de destaque, além de ser muito valorizada no projeto pedagógico do Veredas. Já sabemos que as PPO consistiam em visitas dos tutores às escolas das cursistas a fim de acompanhar uma atividade desenvolvida com os alunos, previamente preparada e discutida nos encontros mensais e que seria, também, objeto de avaliação, além de constituir, no âmbito do processo de formação, carga horária relativa ao estágio supervisionado. Nem sempre esse acompanhamento ocorreu como previsto pelo Veredas. De todo modo, tais visitas foram bem avaliadas pelas professoras cursistas.

O tutor visitava a escola, mas no meu caso isso só aconteceu uma vez. A minha tutora tinha dificuldade em visitar as escolas, pois era muito mal distribuído: numa turma de quinze cursistas ela tinha dez escolas para ela visitar, e aí ainda tinha as atividades dela na faculdade. Estava previsto, mas nem sempre essas visitas aconteciam. Era complicado para o tutor dar assessoria aos professores. A nossa tutora nos disse que a única forma de nos ajudar era por email, pois era muito ocupada. Ela não exigia muito o planejamento de aula para aquela visita, já que ela não podia ir muito. (PC9)

A gente não precisou fazer estágio. A gente era liberada daquele estágio tradicional porque a gente tinha a prática. A tutora ia, embora fosse muito 
pouco, olhava o caderno dos meninos, a dinâmica de sua sala, seu plano de aula, como é que você estava fazendo as coisas, Penso que não era muito fácil para a tutora também, porque, afinal, ela também tinha suas atribuições dentro da universidade. Alguns eram tutores, professores da faculdade de educação e, ainda por cima, escreviam os textos do Veredas. Não era todo tutor que ia à escola, não com a mesma frequência. Dependia muito do grupo. (PC10)

Para as professoras cursistas PC9 e PC10, a visita dos tutores às escolas para acompanhar as PPO não foram realizadas como planejadas durante o curso, tampouco como determinavam as diretrizes do projeto. No relato da PC9 aparece uma questão que não foi resolvida da mesma forma em todos os grupos. Na formação de turmas, a prioridade foi pelo agrupamento de professores da mesma escola, da mesma região e do mesmo município, nesta ordem. Em algumas turmas, todas as professoras cursistas eram da mesma escola e, na maioria, de duas ou três escolas, no máximo. Em alguns casos, tais critérios não foram atendidos, por várias razões, resultando em turmas, como a da PC9, em que havia 15 professoras cursistas distribuídas por 10 escolas; nem sempre próximas. Tudo indica, pelo relato da cursista, que a tutora não conseguiu se organizar para visitar as 10 escolas, duas vezes no semestre, como previa o Veredas, o que a levou, ainda segundo o depoimento, a não ser muito exigente com o planejamento das PPO. Para outras cursistas, a situação foi diferente:

A nossa tutora ia sempre a escola, assistia aulas, via os trabalhinhos dos alunos, visitava as feiras e exposições que a gente organizava. Ela estava sempre presente. Depois da visita era comum a tutora conversar conosco logo após a atividade ou, então, agendar um horário para conversar, mas sempre nos ajudando. Nunca houve broncas, sempre foi para elogiar, incentivar e sugerir coisas. Quando precisava ela também dava uns puxões de orelha, mas sempre de uma maneira elegante. (PC8)

Eu tive a mesma tutora durante todo o curso, então, no final, a gente acabava criando vínculos de amizade, ela nos conhecia bem, nos apoiava, dava as broncas quando era necessário. Era uma relação muito boa. Mesmo tendo o seu tutor, nada impedia que a gente procurasse outros tutores, especialistas de algumas áreas, para tirar dúvidas ou a própria tutora convidava especialistas para abordar temas que a turma não estava conseguindo entender e não era a área dela. (PC16)

Se a gente estava trabalhando no curso com algum conteúdo de matemática, por exemplo, a tutora nos pedia para fazer um plano de atividade para aquele conteúdo, para desenvolvermos na escola. Aconteceu de ela ir à escola acompanhar a atividade umas duas vezes no semestre, ver como a gente estava desenvolvendo aquilo que planejamos durante o curso. No início a gente achava que a visita da tutoria era para nos fiscalizar. Isso dava medo, deixava a gente tensa. Depois, aos poucos, a gente foi percebendo que não era isso, que não se tratava de fiscalização. Não conheço ninguém que tenha tido algum problema com isso. (PC13) 
A situação da tutoria não conseguir fazer as visitas em virtude da distribuição das professoras cursistas em diferentes escolas foi muito comum na região do Vale do Jequitinhonha, em que os professores residiam em municípios diferentes. Lá, de acordo com os depoimentos das cursistas, essas visitas foram esporádicas:

Eu recebi a visita da tutora algumas vezes, agora não sei te falar exatamente quantas, mas sei que não foram duas por semestre, como eles disseram que seriam no primeiro módulo. Eu entendo, sei que não foi por má vontade. A nossa turma tem gente de várias cidades, então é difícil mesmo ficar visitando as escolas. Eu tenho conhecido, em outros polos, que o tutor vai mesmo a escola, assiste aula, vê as atividades das crianças, mas aqui não tem jeito. Assim mesmo, as vezes que a tutora veio foi bacana. Ela não ficou só assistindo as atividades, ela conversou comigo, deu sugestões, até me emprestou alguns materiais. (PC2)

As práticas pedagógicas orientandas foi uma ideia legal do Veredas. Não tinha muito sentido a gente, que já era professora, fazer estágio daquele jeito tradicional. A minha tutora veio assistir minhas aulas algumas vezes. Ela até explicou que não dava para vir mais porque tinha que dividir o tempo entre as outras escolas, nas outras cidades, mas mesmo assim ela veio, viu o que eu tinha feito e disse que estava muito bom. No encontro mensal ela até comentou com o grupo o que eu tinha feito aqui. Durante os encontros ela procurava compensar essa ausência, ficando mais tempo com a gente e até dando atendimento individual, quando a gente precisava. (PC7)

As PPO não eram percebidas pelas cursistas como uma das avaliações do curso. Quando perguntadas como eram avaliadas lembravam-se rapidamente dos CAU, da prova, do memorial e da monografia, não citando as PPO como parte do processo de avaliação, embora houvesse um registro disso. Os tutores encaravam as PPO dessa forma, não se mostrando exigentes demais com o cumprimento desta atividade para fins de avaliação.

O Projeto Veredas foi responsável pela titulação de um grande contingente de professores mineiros e estabeleceu um modelo para este tipo de formação. Alinhada às orientações e recomendações explicitadas nos documentos de agências e organismos internacionais no que tange à formação docente, a proposta mineira foi apontada como uma iniciativa a ser copiada por outros países da América Latina pelo Banco Mundial, que destacou a eficiência do projeto na certificação em massa, com baixo custo, mobilizando instituições de ensino superior públicas e privadas. Vale a pena lembrar que a PPO no Veredas sugere a adesão a uma tendência em alguns países da América Latina, com ênfase na formação associada à prática, em especial Chile (Oficinas de Docentes), Equador (Ciclos de Estudos), Guatemala (Círculos Docentes) e Paraguai (Círculos de Aprendizagem), entre outros. 


\section{TEORIA, PRÁTICA E FORMAÇÃO: TECENDO CONSIDERAÇÕES FINAIS}

Passado o curso, fica o modelo. É preciso destacar, no caso do Veredas, como os sofisticados sistemas que garantiram a arquitetura do projeto agiram no sentido de evitar rupturas ou descontinuidades entre os "modos de pensar", expressos nas concepções e prescrições, e os "modos de operar", expressos nos procedimentos adotados, nas práticas, na lógica da ação. Nesse sentido, podemos afirmar que o projeto admitiu pequenos desvios, resultados, muitas vezes, por uma tensão entre o instituído e o instituinte, ou seja, pelo descompasso entre os modos de pensar e de operar. Exemplo disso pode ser percebido na elaboração de roteiros não previstos pelo sistema instrucional; nas modificações introduzidas na elaboração do memorial e da monografia, como a antecipação do período previsto para elaboração ou na discussão em grupo; no convite a especialistas externos ao projeto, para dirimir as dúvidas dos cursistas; na organização de seminários em que cursistas preparavam as aulas (o que não era permitido pelas diretrizes do curso), pela modificação dos critérios de acompanhamento das práticas pedagógicas orientadas, transformadas, muitas vezes, em exposições ou encontros para discussão; pela flexibilidade na correção dos CAU e no planejamento das PPO, na falta de acompanhamento das PPO mediante visitas às escolas, e tantas outras, como aparecem nos depoimentos de cursistas e tutores. Essas "burlas" eram percebidas como tais, tanto pelos cursistas como pelos tutores; no entanto, eram consideradas normais, como o necessário espaço de autonomia que deveriam ter na condução do curso. Mas nenhum desses desvios alterou de maneira significativa as diretrizes gerais do projeto.

A unidade do projeto foi garantida por meio de guias padronizados, iguais para o extenso território mineiro. Em relação ao currículo, não podemos perder de vista que o Projeto Veredas foi um dos principais programas no âmbito da Escola Sagarana, política que teve como principal característica uma forte centralização no campo curricular em Minas Gerais, justificada pela busca de maior eficiência do sistema educacional medida pelas avaliações de larga escala. Em relação aos conteúdos propriamente ditos, desenvolvidos no Veredas, a análise do material instrucional mostrou que o curso foi totalmente organizado tendo como matriz os parâmetros curriculares nacionais para os anos iniciais do ensino fundamental, o que mostra a adesão do projeto ao currículo nacional.

O Projeto Veredas seguiu firme no propósito de conduzir um curso de formação docente estabelecendo um rol de competências a ser desenvolvido pelos/nos cursistas, nos levando ao elemento estruturante central do currículo adotado, qual seja, uma epistemologia da prática. A um discurso bastante homogêneo no qual se misturaram expressões como 
"habilidades e competências", "aprender a aprender", "trabalho em equipe", entre outras, a ideia de prática esteve sempre presente, tanto para os cursistas como aos tutores. O maior exemplo da importância conferida à dimensão prática no Veredas está explicitado em um dos documentos do projeto ao afirmar que, caso não haja tempo de desenvolver todas as atividades sugeridas, deve-se insistir que o planejamento preliminar de aulas nunca deve ser excluído da programação, pois ele é um elemento básico para a PPO (MINAS GERAIS, 2002d, p. 25)

As PPO, consideradas pelos idealizadores do Veredas como uma inovação, e defendida pela maioria dos tutores como um diferencial do projeto em relação até mesmo ao ensino presencial, materializou no curso o que estava desenhado no projeto, com todas as limitações e ambiguidades presentes nas falas dos sujeitos envolvidos. Para os professores cursistas, o planejamento preliminar das PPO era uma das atividades mais importantes do curso, pois era o momento de ouvir relatos de outras experiências e ter "novas ideias" para o trabalho a ser desenvolvido na escola. Era o "modo de fazer melhor", agora traduzido como um "novo jeito de fazer", presente nos depoimentos dos cursistas.

A assunção de que a produção teórica teria exercido pouco impacto sobre a prática dos professores, como afirmou alguns tutores e cursistas, e daí a importância de se questionar a prática para reorientá-la, colocou o curso na perspectiva de partir da prática para retornar a ela, de tal forma que aos "conteúdos teóricos" caberia o papel de fundamentar essa "prática reorientada" ou, como afirmou uma das tutoras sobre as práticas pedagógicas orientadas, uma “tentativa da teoria habitar a prática". Como nos diz Contreras Domingo (2003), neste contexto

[...] o aspecto fundamental da prática profissional é definido, por conseguinte, pela disponibilidade de uma ciência aplicada que permita o desenvolvimento de procedimentos técnicos para a análise e diagnóstico dos problemas e para o tratamento e solução. A prática suporia a aplicação inteligente desse conhecimento, aos problemas enfrentados por um profissional, com o objetivo de encontrar uma solução satisfatória (CONTRERAS DOMINGO, 2003, p.60)

A ideia de que na PPO se aprendia novos "jeitos de fazer" valorizava o caráter utilitário do conhecimento ou, como disse a maioria dos cursistas, a possibilidade de aplicar o que estava sendo aprendido na escola, na sala de aula, daí a preferência explícita manifestada pelos cursistas pelas oficinas ou pelos componentes curriculares que ensinavam "técnicas novas", coisas passíveis de aplicação imediata, sendo considerados mais difíceis ou menos interessantes aqueles componentes curriculares em que essa "aplicação" não fosse possível ou 
não tão imediata, situação relatada por vários tutores; talvez por isso, para grande parte dos entrevistados, os guias de estudos serviam, apenas, para orientar o preenchimento dos CAU e para a prova final, o que exigia deles um esforço de memorização. Dessa forma, "teoria" e prática" tinham espaços bem demarcados neste processo, o que ficava mais acentuado em conteúdos de disciplinas com pouco impacto na prática docente, como era o caso - segundo os entrevistados - de Filosofia, Sociologia e Antropologia. Paradoxalmente, os "modos de pensar" e os "modos de fazer", cuidadosamente pensados para corrigir desvios na implantação do projeto, não tiveram, no processo de formação, a mesma articulação. Acerca deste distanciamento entre "reflexão teórica" e "práticas", com a exaltação da segunda, Certeau (2001) diz que

A reflexão teórica não escolhe manter as práticas à distância de seu lugar, de maneira que tenha de sair para analisá-las, mas basta-lhe invertê-las para se encontrar em casa. Ela repete o corte que efetua. Este lhe é imposto pela história. Os procedimentos sem discurso são coligidos e fixados em uma região que o passado organizou e que lhes dá o papel, determinante pela teoria, de ser constituídos em "reservas" selvagens para o saber esclarecido [...] Trata-se de um saber não sabido. Há, nas práticas, um estatuto análogo àquele que se atribui às fábulas ou aos mitos, como os dizeres de conhecimentos que não conhecem a si mesmos. Tanto num caso como no outro, trata-se de um saber sobre os quais os sujeitos não refletem. São afinal os locatários e não os proprietários do seu próprio saber-fazer. (CERTEAU, 2001, p. 135-143)

Era de se esperar que um curso organizado com tamanha ênfase na dimensão prática encontrasse uma grande aceitação por parte dos professores cursistas. Para a maioria dos entrevistados a frequência ao curso impactou positivamente sua prática pedagógica, o que aconteceu quando ainda faziam o Veredas. Segundo os depoimentos, a incorporação daquilo que era aprendido no curso ocorria, muitas vezes, de uma forma quase mecânica, favorecida e até mesmo incentivada pelas PPO e pelas visitas dos tutores ao longo dos sete semestres, já que os tutores insistiam com os cursistas para que planejassem as aulas que seriam ministradas na ocasião da visita, a partir dos conteúdos trabalhados no curso. Foram vários os relatos nesse sentido, demonstrando que grande parte do sucesso do Veredas entre os professores se deveu, justamente, a essa correspondência quase imediata entre a realização do curso e as atividades desenvolvidas na escola. A esse respeito, Torres Santomé (2011) faz uma crítica contundente ao que denominou de hipertrofia da prática:

É bastante visível o avanço do que podemos denominar como hipertrofia da formação prática frente a formação teórica, a qual implicitamente, parece ser considerada pouco confiável. Produz-se uma exaltação da experiência e da prática contrapondo-a à teoria. A perda do debate epistemológico é, talvez, a dimensão que melhor está contribuindo para esse tipo de perigosas disfunções nos sistemas educacionais. Essa hipertrofia da prática contribui 
para deixar os professores pelo menos sem preocupação por revisar e contrastar seus marcos teóricos, de modo que possa ter um maior rigor no momento de analisar e valorizar sua prática. Igualmente, esse olhar apenas para o que tem aplicação prática liga-se às necessidades do mercado, sem acesso a outra classe de informação mais relevante [...] Um dos maiores perigos da linguagem das competências é o de tratar de melhorar unicamente as metodologias didáticas, agindo nas tarefas escolares. Esse tipo de linguagem orienta todo o debate em direção a essa dimensão mais prática do conhecimento. (TORRES SANTOMÉ, 2011, p. 190 - grifos no original)

A "prática pedagógica orientada" foi, sem dúvida, o elemento que garantia, ao mesmo tempo, a coesão e a diversificação. De coesão porque se tratava de uma atividade central no projeto de formação, obrigatória aos professores cursistas em todos os polos e, ao mesmo tempo, objeto de avaliação; de diversificação porque permitia aos professores cursistas, de diferentes municípios mineiros, e considerando as suas particularidades e singularidades, organizarem práticas - sob diferentes perspectivas curriculares - apoiadas por tutores e de acordo com os seus planos de ensino.

Para finalizar essas considerações finais, cabe-nos fazer uma observação importante. Para a maioria das professoras cursistas frequentar o Veredas significou mais do que o cumprimento de uma exigência legal de certificação. Expressão como "realizar um sonho" sintetizou bem o que a maioria dizia quando revelava que não esperava ir além do que já tinha conseguido, já que a opção pelo magistério fora determinada pelas oportunidades que se apresentavam no momento da escolha pela profissão. Como bem nos lembra Bourdieu (2009, p. 89), é como se essa correlação estreita entre probabilidades objetivas e esperanças subjetivas impusesse a muitas dessas professoras a interiorização das condições objetivas, daquilo que era possível conseguir em relação à própria formação; nesse sentido, o Veredas surgiu para muitas delas como uma chance objetiva de "realizar o sonho" e de poder falar "de igual para igual", o que certamente colaborou para a avaliação tão positiva que o projeto alcançou entre as docentes.

\section{Referências}

BELLO, I. M. Formação superior de professores em serviço: um estudo sobre o processo de certificação do magistério no Brasil. 2008. 294 f. Tese (Doutorado em Educação). Faculdade de Educação, Universidade de São Paulo, São Paulo: 2008.

BOURDIEU, P. O senso prático. Petrópolis, RJ: Vozes, 2009.

BOUTINET, J.P. Antropologia do projeto. 5. ed., Porto Alegre: Artes Médicas, 2002. 
BRASIL. Ministério da Educação. Lei n. ${ }^{\mathbf{9}}$ 9.394, de 20.12.96. Estabelece as diretrizes e bases da educação nacional. Brasília, DF: Diário Oficial da União, Ano CXXXIV, n. 248, 23.12.96, p. $27.833-27.841$.

CEPAL. Comissão Econômica para América Latina e Caribe. Conclusões e recomendações da conferência sobre educação e desenvolvimento econômico e social na América Latina. Santiago de Chile: CEPAL/OEA/OIT/UNESCO, 1962. In: Pereira, L. (org.) Desenvolvimento, trabalho e educação. Rio de Janeiro: Zahar Editores, 1967.

CEPAL. Comissão Econômica para América Latina e Caribe.Educación y conocimiento: eje de la transformación productiva con equidad. Santiago de Chile: CEPAL/UNESCO, 1992.

CERTEAU, M. A invenção do cotidiano: artes de fazer. 6. ed., Petrópolis, RJ: Vozes, 2001.

CHARTIER, A.M. Fazeres ordinários da classe: uma aposta para a pesquisa e para a formação. Educação e Pesquisa, São Paulo, v. 26, n.2, p. 157-168, jul./dez. 2000.

CONTRERAS DOMINGO, J. A autonomia da classe docente. Porto: Porto Editora, 2003.

DALE, R. Globalization and education: demonstrating a "common world educational culture" or locating a "globally structured educational agenda"? Educational Theory, v. 50, n. 4, p. 427-448, 2000.

ESCHEVARRÍA, J.M. Funções da educação no desenvolvimento. In: PEREIRA, L. (Org.) Desenvolvimento, trabalho e educação. Rio de Janeiro: Zahar, 1967. ("Introdução Geral" do Informe da Conferência sobre Educação e Desenvolvimento Econômico e Social na América Latina realizada em Santiago do Chile em março de 1962).

MINAS GERAIS. Secretaria de Estado da Educação. Veredas. Formação Superior de Professores. Projeto Pedagógico. $2^{\text {a }}$ ed., SEE/MG: Belo Horizonte, 2002a.

MINAS GERAIS. Secretaria de Estado da Educação. Veredas. Formação Superior de Professores. Guia Geral. $2^{\text {a }}$ ed., SEE/MG: Belo Horizonte, 2002 b.

MINAS GERAIS. Secretaria de Estado da Educação - SEEMG. Veredas. Formação Superior de Professores. Manual de avaliação de desempenho de cursistas do Veredas. $2^{\mathrm{a}}$ ed., Belo Horizonte, 2002c.

MINAS GERAIS. Secretaria de Estado da Educação. Veredas. Formação Superior de Professores. Manual de Tutor. $2^{\text {a }}$ ed., SEE/MG: Belo Horizonte, 2002d.

POPKEWITZ, T.S.; PEREYRA, M. Estudio comparado de las prácticas contemporáneas de reforma de la formación del profesorado en ocho países: configuración de la problemática y construcción de uma metodología comparativa. In: POPKEWITZ, T. S (Comp.). Modelos de poder y regulación social en pedagogía: crítica comparada de las reformas contemporáneas de la formación del profesorado. Barcelona: Pomares- Corredor, 1994, p. 15-91.

POPKEWITZ, T.S.; PEREYRA, M. Reforma educacional: uma política sociológica - poder e conhecimento em educação. Porto Alegre: Artmed, 1997. 
PREAL. Programa de Promoción de la Reforma Educativa en América Latina y el Caribe. Informe de la Comisión Centroaamericana sobre la Reforma educativa para la Educación: mañana es muy tarde. Santiago do Chile: PREAL, 1999.

PREAL. Programa de Promoción de la Reforma Educativa en América Latina y el Caribe. Quedándonos atrás: un Informe del progreso Educativo em América Latina. Santiago, Chile: Preal, 2001.

SARAVIA, L. M.; FLORES, I. La formación de maestros en América Latina: estudio realizado en diez países. Ministerio de Educación - DINFOCAD - PROEDUCA-GTZ: Lima, Peru, 2005.

TENTI FANFANI, E. La condición docente: datos para el análisis comparado Argentina, Brasil, Perú y Uruguay. Buenos Aires: Siglo Veintiuno, 2005.

TORRES SANTOMÉ, J. Evitando o debate sobre a cultura no sistema educacional: como ser competente sem conhecimento. In: GIMENO SACRISTÁN, J. Educar por competência: o que há de novo? Porto Alegre: Artmed, 2011, p. 161-197. 